\title{
Form of Supervision of a Pawnshop Company based on OJK Regulation No.31 / POJK.05 / 2016 Concerning Purpose Businesses
}

\author{
Lathifah Hanim ${ }^{1}$, Maryanto ${ }^{2}$, Munsharif Abdul Chalim ${ }^{3}$, Andri Winjaya Laksana ${ }^{4}$ \\ Faculty of Law, Universitas Islam Sultan Agung, Indonesia ${ }^{1,2,3,4}$ \\ \{lathifah.hanim@yahoo.co.id $\left.{ }^{1}\right\}$
}

\begin{abstract}
Pawnshop supervision is needed to create a healthy pawnshop business, provide legal certainty for pawnshop business actors and protect consumers. The formulation of the problem is what form of supervision of pawnshops based on OJK Regulation No.31 / POJK.05 / 2016 concerning Pawnshop Business? The research method used is juridical empirical. Results of the research: The form of supervision of pawnshops carried out by OJK based on OJK Regulation No.31 / POJK.05 / 2016 concerning Pawnshop Business is the supervision carried out by OJK on pawnshops carried out in 2 (two) ways, namely: a). Off-site supervision, namely the OJK conducts analysis of periodic reports submitted by PT Pegadaian (Persero) on a monthly basis, and those submitted by private pawnshops on a quarterly basis. and b.) On-site supervision, namely by means of examining to obtain adequate assurance of the accuracy of periodic reports submitted by pawnshops and assessing compliance with statutory provisions applicable to the Pawnshop industry.
\end{abstract}

Keywords: Pawnshop Supervision, OJK

\section{Introduction}

In the economic system in Indonesia, the Financial Services Authority (hereinafter referred to as $\mathrm{OJK}$ ) is a recognized institution that carries out supervision of the financial services sector. The existence of the OJK in the financial system and in the activities of the financial services sector is particularly important. This is primarily related to issues of regulation formation and supervision of the financial services sector. The creation of integrated and comprehensive regulations and supervision in the financial services sector that carries out an intermediation function will make a significant contribution to the provision of funds to finance national economic development.

The definition of a pawnshop business is all business related to providing loans with collateral for movable goods, deposit services, estimation services, and / or other services, including those organized based on sharia principles (POJK No.31 / POJK.05 / 2016 Article 1). The operation of a pawnshop business (or often called a pawnshop, pawnshop service business) expands financial services by providing easy access to loans, especially for the lower middle class and micro, small and medium enterprises that cannot meet the 
requirements to obtain funding from financial institutions such as banks and multi-finance companies. Pawnshops are here to provide solutions by being able to provide cash in an easy, fast and simple procedure for the community. The existence of regulations governing the Pawnshop Business is considered very urgent. OJK Regulation No. 31 / PJOK.05 / 2016 concerning Pawnshops, contains the obligations of pawnshops companies to obtain a business license from the OJK as well as the minimum standards that must be met by pawnshops in carrying out business activities.

Pawnshops are private pawnshops and government pawnshops that are regulated and supervised by the Financial Services Authority. A private pawn company is a legal entity that operates a pawnshop business. Government Pawnshop Company is PT Pegadaian (Persero) as referred to in Staatsblad Year 1928 Number 81 concerning Pandhuis Reglement and Government Regulation Number 51 Year 2011 concerning Changes in the Form of a Public Company Legal Entity (Perum) Pegadaian to become a Limited Liability Company (Persero).

Based on the description above, the author is interested in examining it, namely by conducting research entitled "Forms of Supervision of Pawnshops Companies based on OJK Regulation No.

\section{Problem Formulation}

What is the form of Supervision of Pawnshop Companies based on OJK Regulation No.31/ POJK.05 / 2016 concerning Pawn Shops?

\section{Research Methods}

Research on the form of Supervision of Pawnshop Companies based on OJK Regulation No.31 / POJK.05 / 2016 concerning Pawnshops, uses the concept of law where law is positive norms in the national legal system of legislation, with 2 (two) approaches, namely qualitative and quantitative. This research uses qualitative research. This research is based on law research which is conducted with doctrinal and non-doctrinal approaches. This research is also based on the legal positivist concept which states that legal norms are identical to written norms and are made and promulgated by competent state institutions.

Sources and types of data consist of:

a) Secondary data, the type of data used in the doctrinal approach is secondary data. When viewed from the point of view of the information provided, library materials can be divided into 3 (three) groups, namely primary legal materials, secondary legal materials, and tertiary legal materials.

b) Primary data, namely data obtained directly from the main source in the form of views, thoughts, aspirations, actions, events and legal relationships and words. This type of data provides information or information directly about everything related to the object of research, which is obtained directly through the field in the form of words and actions by means of in-depth interviews.

This research is an analysis with 2 (two) stages:

a) The first stage which is based on a doctrinal approach, the analysis is carried out using the qualitative normative analysis method.

b) The second stage is based on an empirical approach, the analysis is carried out using qualitative analysis which is carried out using interactive analysis methods (interactive 
models of analysis). The three stages are: data reduction, data display and drawing conclusion data.

\section{Result and Discussion}

The form of supervision of pawn shops is based on OJK Regulation No.31 / POJK.05 / 2016 concerning Pawnshops. Law Number 21 of 2011 concerning the Financial Services Authority (OJK) has stipulated that a pawnshop is a financial service institution that is under OJK regulation and supervision. However, until now there are no laws and regulations governing pawnshop business activities, so pawnshop business activities have not been supervised. It is feared that this condition could cause losses to customers.

OJK is a state institution established based on Law No. 21 of 2011 which functions to organize a system of regulating and supervising all activities in the financial services sector in the banking sector, capital market and non-bank financial services sectors such as insurance, pension funds, financial institutions and other financial service institutions.

Based on Law no. 21 of 2011 concerning the Financial Services Authority (OJK), a pawnshop business is a financial service institution that is regulated and under the supervision of the OJK. In carrying out its supervisory function, OJK requires a legal umbrella in the pawning business. the legal basis for the Financial Services Authority (OJK) in supervising pawnshops in Indonesia. This POJK contains the obligations of a pawnshop company to register, obtain a business license from the OJK and meet the minimum standards that companies must meet in carrying out pawnshop business activities.

$\mathrm{OJK}$ is an independent institution and free from interference from other parties, which has the function, task and supervisory authority as referred to in Law Number 21 of 2011 concerning the Financial Services Authority (hereinafter referred to as the OJK Law). The establishment of this supervisory institution was initiated by the mandate of Article 34 paragraph (1) of Act Number 23 of 1999 concerning Bank Indonesia, which was later amended and enhanced by Act Number 3 of 2004, last amended again by Act Number 6 years 2009 concerning Bank Indonesia. which states that the task of supervising banks will be carried out by an independent financial services sector supervisory institution, and is established by law and paragraph (2) which states that the establishment of a supervisory institution will be carried out by December 31, 2002.

OJK must be able to safeguard national interests, including, among other things, human resources, management, control and ownership in the financial services sector, while still considering the positive aspects of globalization. Furthermore, because of this, there was a transition period where previously the supervision and regulation of the Capital Market and Non-Bank Financial Industry was still at the Capital Market Supervisory Agency and Financial Institutions and the Ministry of Finance, then in the transitional provisions of Article 55 paragraph (1) of Law Number 212011 concerning the Financial Services Authority. Since December 31, 2012, the functions, duties and authorities of regulating and supervising Financial Services activities in the Capital Markets, Insurance, Pension Funds, Financing Institutions and Other Financial Services Institutions sector have been transferred from the Minister of Finance and the Capital Market and Financial Institution Supervisory Agency to the Authority. Financial Services. The Capital Market and Financial Institution Supervisory Agency (Bapepam-Financial Institutions) is an institution under the Ministry of Finance that is tasked with fostering, regulating and supervising the day-to-day activities of the capital market as well as formulating and implementing policies and technical standardization in the field of 
financial institutions starting from the capital market sector., pension funds, insurance, financing and guarantee institutions. As a consequence of the issuance of the OJK Law, that the Capital Market Supervisory Agency and Financial Institutions are no longer under the Ministry of Finance, all authorities in Bapepam - Financial Institutions ranging from Capital Markets, Insurance, Pension Funds, Financing Institutions, and Other Financial Services Institutions are transferred to OJK and Bapepam - Financial Institutions disappeared and joined the OJK.

OJK was formed to overcome weaknesses and lack of supervision in the financial sector in Indonesia, but the actual implementation of these institutions to achieve its objectives is the most difficult and a challenge for the State of Indonesia. The formation of the OJK gave high hopes to the Indonesian government, the Financial Services Industry community, and even the Indonesian people in general. Expectations for OJK must be handled fairly, namely in terms of the ability to carry out operational executions in accordance with the demands of the community, as well as the ability to become an independent institution that puts forward the best practices of good corporate governance and risk management so that no reputation is harmed. In this regard, OJK will face reputational risks that can affect public confidence and the financial services industry in it and in turn have an impact on the development of the financial services sector in Indonesia that it supervises.

The Financial Services Authority (OJK) carries out its duties and authorities based on the following principles:

a) The principle of independence, namely being independent in decision making and implementing the functions, duties and authorities of the OJK, while remaining in accordance with applicable laws and regulations.

b) The principle of legal certainty, namely the principle in a rule of law that prioritizes the foundation of statutory regulations and justice in every policy of implementing the Financial Services Authority.

c) The principle of public interest, namely the principle of defending and protecting the interests of consumers and society and advancing public welfare.

d) The principle of openness, namely the principle of opening oneself to the rights of the public to obtain true, honest, and non-discriminatory information regarding the administration of the Financial Services Authority, while still paying attention to the protection of individual and group human rights, as well as state secrets, including secrets as stipulated in the legislation. -invitation.

e) Professionalism principles, namely principles that prioritize expertise in the implementation of the duties and authorities of the Financial Services Authority, while remaining based on the code of ethics and the provisions of laws and regulations.

f) The principle of integrity, namely the principle of upholding moral values in every action and decision taken in the administration of the Financial Services Authority.

g) The principle of accountability, which is the principle that determines that every activity and the final result of every activity of the Financial Services Authority must be accountable to the public.

The formation of this supervisory institution for the financial services sector, its formation in Indonesia is regulated and inaugurated on 22 November 2011 through Law Number 21 of 2011 concerning the Financial Services Authority. OJK is an independent institution in carrying out its duties and authorities, free from interference from other parties, except for matters regulated in this OJK law. The objective of OJK's independence is needed so that the ability to regulate and supervise the operation of financial institutions in Indonesia can be carried out properly and firmly. In addition to the above considerations, the formation of the 
Financial Services Authority originated from the occurrence of the globalization process in the financial system and the rapid progress in the field of information technology and financial innovation has created a financial system that is very complex, dynamic and interconnected between financial sub-sectors both in terms of products and institutions.

The supervisory duties of the non-bank financial industry and capital market officially shifted from the Ministry of Finance and Bapepam-LK to OJK on 31 December 2012. Meanwhile, supervision in the banking sector shifted from Bank Indonesia to OJK on 31 December 2013 and micro financial institutions in 2015. Authorities Financial Services (OJK), which is an integrated institution in the overall regulatory and supervisory system for activities in the financial services sector, namely financial services activities in the banking sector, financial services activities in the capital market sector and financial services activities in the insurance sector, pension funds, financial institutions, and other financial service institutions, namely Microfinance Institutions. Based on Article 28 of Law Number 1 of 2013 concerning Micro Financial Institutions (UU LKM), it is stated that the guidance, regulation and supervision of Micro Financial Institutions (LKM) are carried out by the Financial Services Authority.

In carrying out its supervisory function, OJK has consistently implemented a supervisory approach including enforcement as a follow-up to supervisory actions. In the banking industry, risk-based supervision from entry to exit, both off-site and on-site, has been consistently carried out, as well as its enforcement.

In enforcing consumer protection, OJK has served 117,009 service requests with a completion rate of 97.09 percent. The Investment Alert Task Force has succeeded in freezing $1,898 \mathrm{P} 2 \mathrm{P}$ lending fintechs, prosecuting 444 illegal investment companies and 68 illegal pawns. In the context of increasing literacy and opening public financial access, through various initiatives OJK has succeeded in increasing the index of financial literacy and inclusion, as evidenced by the results of the literacy survey which increased from 29.7 percent to 38 percent and financial inclusion increased from 67.8 percent to 76.2 percent. This figure has met the target mandated by the government.

The Financial Services Authority inaugurated the OJK-Box or OBOX application as an effort to strengthen supervision of the Information Technology-based financial services sector, which has started its application in the banking sector. The information technology-based supervision strengthening program is one of the priority programs of the 2019 OJK strategic policy. This is also part of the Business Process Re-engineering of the supervisory process by utilizing technology. OBOX is an application that allows Banks to improve the flow of information to the OJK, especially transactional information. This information will complement existing reports so that OJK and the Bank can raise attention to potential risks that arise early.

OBOX application development is carried out in 2 (two) phases. Phase 1 (one) is applied to 10 Bank Pilot Projects which began to be implemented on May 13, 2019. Meanwhile, implementation of phase 2 (two) covering 104 other Commercial Banks will be carried out in stages until the end of December 2019. Going forward, the development of the OBOX application will be the first step. OJK in adopting the information technology-based supervision paradigm (suptech / supervisory technology) is currently developing in the global financial world.

Strengthening Information Technology-based supervision is also in line with developments in financial product and service innovations in the financial services industry which are increasingly complex and require a more responsive supervisory pattern to anticipate potential problems that could disrupt the health of the financial services industry. Therefore, it is 
necessary to improve the supervision process by utilizing information technology innovations as an effort to increase the efficiency and effectiveness of the implementation of OJK's duties and functions.

Monitoring activities can be more optimal because data and information are already available earlier in the OBOX application. In the future, the on-site examination activities will focus more on confirming the results of the analysis of the data and information that have been carried out previously. This application will also benefit the financial services industry because it will reduce the load and time for on-site inspection services, accelerate the response to examination results, accelerate the development of early warnings and action plans and build trust between supervisors and the financial services industry.

Some of the legal considerations in the Financial Services Authority Regulation No.31/ PJOK.05 / 2016 include increasing financial inclusion for the middle to lower class communities and micro, small and medium enterprises need to expand financial services through the implementation of pawnshops, in the context of conducting business pawnshops that provide easy access to loans, especially for middle to lower and micro, small and medium enterprises, there is a need for a legal basis for the Financial Services Authority in supervising pawnshops in Indonesia, for supervision of pawnshops is needed to create healthy pawnshops, providing legal certainty for pawnbrokers and consumer protection.

As an independent supervisory agency that has just been established and operates in Indonesia, OJK is expected to be able to make the financial services sector operate better. The formation and implementation of the OJK will bring challenges as well as risks. The government and the people of Indonesia are expected to be able to handle the risks raised by the new independent institution, by reviewing legal regulations and implementing the duties and functions of the OJK as an independent supervisory agency. It is necessary to hold an integrated selection and training process in the operation of the OJK so that the institution can be supported by a reliable system and human resources. Training in human resources in the financial services industry is also needed in order to produce risk management professions who are able to deal with emerging risks.

In Indonesia, integrated supervision between Financial Service Institutions (LJK) in the financial sector has been formed. This institution is the Financial Services Authority (OJK), which is the supervisor of the capital market, banking and non-bank financial institutions which began operating effectively on January 1, 2014. OJK is in charge of overseeing the banking industry, capital market (listed or issuers, securities companies, investment managers. ), insurance, finance companies, pension funds, pawnshops, Social Security Management Agency (BPJS) to microfinance institutions.

OJK monitors pawnshops in 2 (two) ways, namely:

a) Off-site supervision, namely OJK conducts an analysis of periodic reports submitted by PT Pegadaian (Persero) on a monthly basis, and those submitted by private pawnshops on a quarterly basis.

b) On-site supervision, namely through examinations to obtain sufficient assurance of the accuracy of periodic reports submitted by pawnshops and assessing compliance with statutory provisions applicable to the Pawnshop industry.

OJK is expected to be able to effectively supervise interconnected financial institutions. For example, capital market products offered through banking. Or also the supervision of a business group that is an issuer, and has subsidiaries in banks, insurance and other financial service institutions.

Looking back at its functions and duties, the OJK functions to organize an integrated regulatory and supervisory system for all activities in the financial services sector. This 
integrated supervision also applies to financial conglomerates. What is meant by conglomeration is a holding company in which there are subsidiaries in the financial services sector. Thus, OJK has the authority to oversee the activities of this conglomerate holding company.

Important things to monitor are the risks of the parent company that could threaten the interests of customers or investors. This means that risk-based supervision is carried out not only for financial service institutions, but also for conglomerates of financial service institutions within a business group, because of their relationship to business ownership or control. With the existence of integrated supervision, significant risks that arise in the financial services sector can be detected early, so that supervisory actions can be taken accordingly and on time. There are 3 (three) levels of supervision carried out by OJK. The first level is supervision of financial institutions on an individual basis (solo basis). The second level is downstream consolidated supervision or supervision of financial institutions and subsidiaries in the financial sector. The third level is downstream and upstream consolidation supervision or in the form of consolidated supervision of financial conglomerates.

This integrated supervision goes through a number of stages, namely, understanding of the financial conglomerate, assessing the risk and condition of the financial conglomerate, planning the supervision, coordinating the inspection, updating the risk profile and level of the condition of the financial conglomerate, as well as monitoring and monitoring actions. OJK regarding integrated supervision, in carrying out certain stages in the integrated supervision cycle based on risks to financial conglomerates, coordination must be carried out between integrated supervisors and individual supervisors and through integrated supervisory panel forums based on risks to financial conglomerates.

OJK shall supervise pawn shops. Supervision of pawnshops is carried out based on OJK Regulation No. 31 / POJK.05 / 2016 concerning Pawnshop Business and its implementing regulations. In the framework of implementing the supervisory function of pawnshops, OJK has the authority to conduct examinations of pawnshops.

The examination is carried out by an examination team consisting of:

a) OJK employees assigned to carry out the examination.

b) Other parties appointed by OJK; or

c) Merger between OJK employees and other parties appointed by OJK.

Examination of each Pawnshop Company is carried out:

a) Periodically in accordance with the annual inspection plan stipulated by the OJK; an / or

b) Any time if needed.

The examination is carried out by the Examiner based on the Audit notification letter. Before the examination is carried out, first a notification letter of the Audit is submitted to the Pawnshop Company. The inspection notification letter contains the following information: a). number and date of the Audit warrant; b). Examiner name.c). Examination Purpose; d). Audit Period; e). documents required for the Inspection; and f). The deadline for submitting documents to the examiner.

Audit notification letter is submitted no later than 3 (three) days prior to the date of the inspection activity. This provision is excluded if the submission of the Audit notification letter is suspected to complicate or hinder the Audit process or will allow actions to be taken to obscure the actual situation or hide or eliminate data, information, or reports, which are required in the implementation of the Audit activities.

The examination of the Pawnshop Company is carried out in stages, namely: a). Examination Preparation; b). Implementation of Audit activities; and c). Reporting of examination results. The inspection preparation is made based on the results of periodic report 
analysis and other supporting data. Examination activities are carried out by means of an examination at a pawnshop company, an inspection at the OJK office, or an inspection at another place determined by the OJK.

At the time the Audit is about to begin, the Examiner shows the Inspection warrant and the examiner's identification. In the event that the Examiner fails to comply with these provisions (warrant and identification), the Pawnshop company that will be examined may refuse to conduct the Audit. The examiner is obliged to keep the data, documents, and / or information obtained during the examination of unauthorized parties in secret, except for the purpose of carrying out their functions, duties and authorities based on OJK decisions or required by law. Further provisions regarding inspection procedures are specified in the OJK Circular.

At the time of the Audit, the inspected Pawnshop Company is obliged to:

a) Fulfill requests to provide or lend books, files, records, dispositions, memoranda, documents, electronic data, including copies thereof.

b) Provide information and explanations relating to the aspects examined both orally and in writing.

c) give the opportunity to the examiner to enter and examine the place or room deemed necessary.

d) give the opportunity to inspectors to examine the existence and use of physical facilities related to the aspects being examined; and / or

e) Bringing third parties, including independent auditors, to provide data, documents and / or information to Examiners related to the Audit.

The pawnshop company has an internal control systemSistem Pengendalian Internal PT.Pegadaian that includes five components, namely:

a) Supervision by management and development of a risk awareness culture.

b) Identification and risk assessment.

c) risk control activities and separation of functions.

d) Accounting, information and communication systems.

e) Monitoring activities and corrective actions for deviations.

Every work unit operational process activity at Pegadaian is guided by standard operating procedures in which an adequate internal control system is attached. The effectiveness of work unit internal controls is reviewed periodically by Internal Supervisors at branch offices, regional offices and head office.

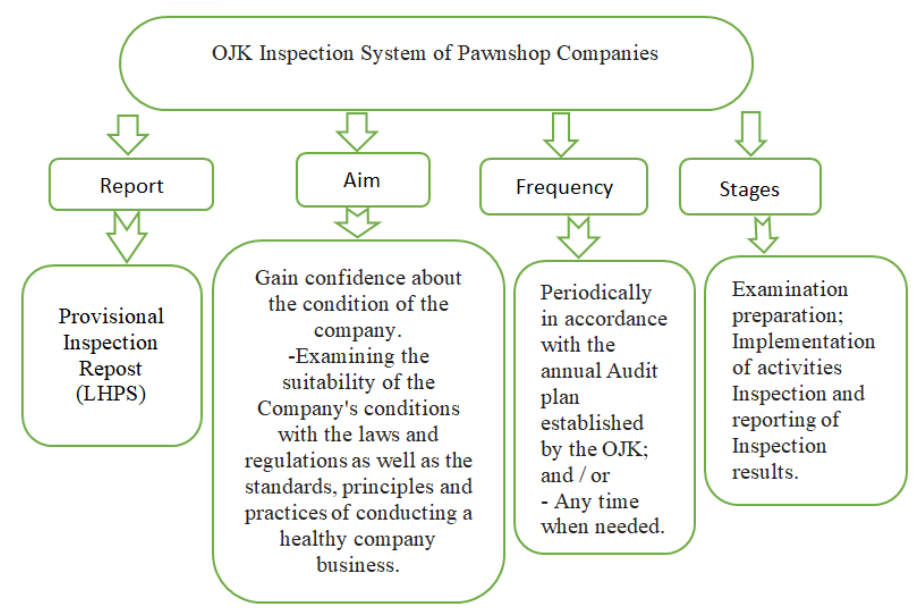

Fig. 1. OJK Inspection System of Pawnshop Companies 
Pawnshops are committed to implementing Governance (GCG) practices in increasing value, competitiveness and sustainable long-term business growth. The implementation of GCG is not only for the interests of shareholders (shareholders) but also for all other stakeholders, in the sense that business management is not only for profit but also management that is full of trust, transparency and accountability.

The supervision carried out by the Pawnshop Company includes the operational activities of the Pawnshop Company, operational guidelines and marketed products, development, assessment, and recommendations for the business activities of the Pawnshop Company which include products, operations and marketing.

Pegadaian provides loan services through a variety of products. Apart from loan products, there are also investment products which are indeed additional service products at Pegadaian. There are four product lines contained in Pegadaian. The first line is products related to lending, the second line is more towards payments, the third line is gold investment which is currently popular in the community, the fourth line is a variety of services products.

Pegadaian products include 1). Conventional Pawn Products (this type of pawnshop product is the one most recognized by the public. This service makes it easy to get liquid funds by pledging an item to Pegadaian, the interest charged for this one pawnshop product is relatively low, namely $0.75-1.15$ percent per 15 days). 2). Sharia Pawn Product (Rahn) - this product does not recognize the same capital lease as loan interest. In exchange, this sharia pawning product applies rent (ujrah) to each borrower. 3). Fiduciary Based Products. (This product is intended to provide funds for productive businesses in all sectors with movable or immovable objects that cannot be burdened with mortgages. 4). Installment system pawn products (products made as credit for micro-entrepreneurs. The borrower will get a fresh amount of funds from the pawning of valuable goods. The borrower makes loan payments in installments). Gold Investment Products (intended for people who want to own precious metals in cash or in installments). 6). Estimation Services (providing value testing services for movable goods, such as gold jewelery, so that the party who intends to buy the item does not play tricks or tricks). 7). Custodian Services (For those who are worried about the security of their valuables, the storage solution is through a deposit service product issued by Pegadaian, by paying rent for a place).

Pegadaian products also consist of 1). Pegadaian KCA (Fast Secure Credit) Prima provides loan services with guarantees suitable for students or college students. 2). Non-Cash KCA (Fast Secure Credit) Pegadaian - loan funds are provided via bank transfer making it easier, faster and safer. Items that can be guaranteed are in the form of gold jewelry, gold bars, diamonds, laptops and other valuables. 3). Pegadaian Kreasi Flexi - a loan with collateral specifically for farmer and non-farmer customers. Payment can be made by a single payment or installment method. The pledged goods were motor vehicles, gold, production equipment and supplies. 4). Pawn Fleks - KCA (Fast Secure Credit) credit service that provides low interest funding solutions. 5). Business Pawn - is a solution for customers who need business funding loans. Loans are given up to Rp. 1 billion, with collateral in the form of gold bars and jewelry. 6). Krasida - a monthly installment loan provided to Micro, Small and Medium Enterprises (MSMEs), collateral for gold jewelry or motor vehicles. 7). Kreasi - a monthly installment loan provided to MSMEs with a motorized vehicle BPKB guarantee. 8). Rahn Financing - is a sharia pawnshop product whose rules refer to Islamic law. 9). Arrum BPKB Financing - a sharia loan that follows the principles of Islamic law. 10). Amanah - Islamic pawnshop loan aimed at customers who want to buy a car or motorcycle. 11). Arrum Haji - a gold pawnshop feature for customers who want to go on the pilgrimage. The guarantee received is a minimum of 7 million gold. 
The supervision and inspection of Pawnshops is regulated in OJK Regulation No.31 / POJK.05 / 2016 concerning Pawnshops. Chapter VIII Part One Pawnshop Company Supervision, namely supervision of Pawnshop companies carried out by OJK. The legal basis for supervision of pawnshops is needed to create a healthy pawnshop business, provide legal certainty for pawnshop business actors and protect consumers.

Article 41 of OJK Regulation No.31 / POJK.05 / 2016 concerning Pawnshop Businesses states that OJK shall carry out supervision of Pawnshops. The form of supervision as referred to in Article 41, OJK can conduct inspections of pawnshops by assigning OJK employees or other parties or a combination of OJK employees and other parties that have been appointed by OJK to carry out inspections. OJK's inspection schedule for pawnshops is carried out periodically in accordance with the annual inspection plan that has been regulated by the OJK. However, if necessary, OJK may occasionally carry out an examination outside the stipulated schedule. Before conducting an inspection, the OJK must submit an inspection notification to the pawnshop company.

Article 44 paragraph (5) of OJK Regulation No.31 / PJOK.05 / 2016, the provisions referred to in paragraph (2) are exempted if the submission of an inspection notification letter is suspected to complicate or hinder the examination process or will allow actions to obscure the true situation or conceal it or omit data, information, or reports, which are required in the implementation of inspection activities.

\section{Conclusion}

The form of supervision carried out by OJK on pawnshops is carried out in 2 (two) ways, namely:

a) Off-site supervision, namely the OJK conducts analysis of periodic reports submitted by

PT Pegadaian (Persero) on a monthly basis, and those submitted by private pawnshops on a quarterly basis.

b) On-site supervision, namely through examinations to obtain sufficient assurance of the correctness of periodic reports submitted by pawnshops and assessing compliance with statutory provisions applicable to the Pawnshop industry.

Pawnshop business supervision is needed to create healthy pawnshops, provide legal certainty for pawnshops and for consumer protection. In order to supervise pawnshops in the community, the Pegadaian must first register with the OJK. With supervision, Pegadaian continues to make improvements in order to adapt to the challenges of the times by developing a number of digital products and services to provide convenience and added value to customers. Thus Pegadaian has supported the government's efforts to develop a national economy based on a populist economy for the sake of realizing the nation's economic independence.

\section{References}

[1] UUD Negara Republik Indonesia Tahun 1945

[2] KUHPerdata

[3] Undang-undang Nomor 10 Tahun 1998 tentang Perbankan

[4] Undang-Undang Nomor 6 tahun 2009 tentang Bank Indonesia

[5] Undang-undang Nomor 21 tahun 2011 tentang Otoritas Jasa Keuangan (OJK). 
[6] Peraturan OJK No.3/PJOK.05/2013 tentang Laporan Bulanan Lembaga Jasa Keuangan Non-Bank.

[7] Peraturan OJK No.31/PJOK.05/2016 tentang Usaha Pergadaian.

[8] Surat Edaran OJK No.12/SEOJK.05/2013 tentang Laporan bulanan PT.Pegadaian (Persero)

[9] Surat Edaran OJK No.51/SEOJK.05/2017 tentang Pendaftaran, Perijinan Usaha, dan Kelembagaan Perusahaan Pergadaian.

[10] Surat Edaran OJK No.52/SEOJK.05/2017 tentang Penyelenggaraan Usaha Perusahaan Pergadaian yang Menyelenggarakan Kegiatan Usaha secara Konvensional.

[11] Irham Fahmi, Bank dan Lembaga Keuangan Lainnya Teori dan Aplikasi, Alfabeta, Bandung, 2016, hlm. 16

[12] Lexy J. Moleong, Metodologi Penelitian Kualitatif, Remaja Rosdakarya Offset, Bandung, 1998, hlm.112

[13] Ratna Syamsiar, Hukum Perbankan, Justice Publisher Badan Penerbitan Fakultas Hukum Universitas Lampung, Bandar Lampung, 2014, hlm. 163

[14] Ronny Hanitiyo Soemitro, Metodologi Penelitian Hukum, Ghalia Indonesia,Jakarta, 1990, hlm. 32

[15] Sistem Pengendalian Internal PT.Pegadaian.

[16] Wimboh Wimboh Santoso, Ketua Dewan Komisioner Otoritas Jasa Keuangan, Kata Sambutan Pada Rapat Kerja OJK dengan Komisi XI DPR, Selasa 4 Februari 2020. 